\title{
NAUCZANIE KOMPETENCJI INFORMACYJNYCH NA PRZYKŁADZIE PRAKTYK STOSOWANYCH W DOCKLANDS LIBRARY UNIWERSITY OF EAST LONDON
}

\author{
Katarzyna Cyran \\ Monika Gościk \\ Biblioteka Państwowej Szkoły Wyższej \\ im. Papieża Jana Pawła II \\ w Białej Podlaskiej
}

Erasmus, Docklands Library University East of London, Information literacy, Info Skills, kompetencje informacyjne

„Nauka może mieć miejsce w każdym miejscu i o każdej porze, ma ona często charakter nieformalny i pozbawiony struktury. Wiedzy nie zdobywa się raz na zawsze. Nauka jest częścią procesu wzrastania każdego człowieka jako osoby i oddychania pełnią życia"'. Bibliotekoznawstwo i informacja naukowa to stale ewoluujące i poszerzające swój zakres dziedziny, co obliguje specjalistów bibliotecznych do szukania możliwości ciągłego dokształcania się i zdobywania nowych kompetencji zawodowych, by móc dotrzymać kroku nie tylko szybko rozwijającej się technologii, ale też coraz bardziej złożonym potrzebom informacyjnym użytkowników - dyplom staje się w obecnych czasach nie końcem nauki, lecz dopiero początkiem edukacji bibliotekarza². Wizyty w bibliotekach lub ośrodkach informacji to doskonała okazja do podnoszenia kwalifikacji. Umożliwiają spotkania z personelem, dyskusje oraz zaznajomienie się z tym, co dzieje się w tych instytucjach, ułatwiają poznanie innych systemów, stanowią zachętę do przejmowania nowych i korzystnych rozwiązań ${ }^{3}$.

Program ERASMUS ${ }^{4}$ wyrównuje szanse bibliotekarzy na zdobywanie wiedzy i doświadczenia, daje szansę na zacieśnianie kontaktów i podejmowanie

${ }^{1}$ Zarządzanie biblioteką. Najnowsze kierunki w bibliotekarstwie brytyjskim: wybór tekstów. Pod red. I. Kemp, T. Wildhardt. Warszawa 1998, s. 107.

${ }^{2}$ M. Waleszko: Zawodowy rozwój 2.0 dla bibliotekarzy: tworzenie osobistej sieci ksztatcenia online. Za: N. A. Cooke: Professional development 2.0 for librarians: developing an online personal learning network (PLN) (Rozwój zawodowy 2.0 dla bibliotekarzy: rozwój osobistej sieci kształcenia online). „Library Hi Tech News”. 2012, vol. 29, no. 3, p. 1-10. [online]. [dostęp: 24.06.2012]. Dostępny World Wide Web (dla subskrybentów) w: emeraldinsight.com.

${ }^{3}$ Zarządzanie biblioteką. Najnowsze kierunki w bibliotekarstwie brytyjskim..., op. cit., s. 107.

${ }^{4}$ ERASMUS powstał w 1987 r. jako sposób na propagowanie i ułatwianie wymiany studentów między uczelniami krajów Wspólnoty Europejskiej. Od 2007 r. jest częścią szerszego projektu - Education and Culture Lifelong Learning Programme (czas trwania 20072013; budżet: 6970000000 euro), którego główną idea jest uczenie się przez całe życie. Obecnie program obejmuje też pracowników różnych sektorów uczelni, w tym pion administracyjny. Erasmus [online]. [dostęp: 2.10.2012]. Dostępny w World Wide Web: <http:// www.erasmus.org.pl>. 
wspólnych międzynarodowych czy międzyregionalnych inicjatyw w zakresie doskonalenia usług, jakie świadczą biblioteki. Dzięki niemu bibliotekarze, z różnym stażem zawodowym i na różnym szczeblu zawodowej kariery, mają możliwość nadażania za szybko postępującymi zmianami i rozwojem naukowo-technologicznym ${ }^{5}$.

W kwietniu 2012 r. dwóch pracowników Biblioteki Państwowej Szkoły Wyższej (PSW) im. Papieża Jana Pawła II w Białej Podlaskiej odbywało tygodniowy staż (Staff Training Mobility) w ramach programu ERASMUS w Docklands Library University East of London. Biblioteka w kampusie Docklands jest jednym $z$ trzech centrów informacyjnych uniwersytetu. Jest to nowoczesny budynek, doskonale przystosowany do potrzeb studentów, wyposażony w udogodnienia technologiczne. Budynek usytuowany jest nad woda. Jedna ze ścian czytelni jest przeszklona, co daje naturalne światło, a widok wodnego akwenu koi wzrok. Biblioteka jest otwarta przez cała dobę. Statystyki wejść potwierdzają zasadność takiego rozwiązania. Biblioteka oferuje usługi tradycyjne, ale również udostępnia swoje zasoby elektronicznie. Użytkownicy otrzymują hasło Athens ${ }^{6}$ i moga z biblioteki korzystać również poza kampusem, a mimo to w bibliotece zawsze można zastać wiele osób pracujacych przy komputerach, czytających czy siedzących na miękkich pufach między regałami. Użytkownicy w różnych momentach potrzebuja różnych środowisk nauczania, dlatego przestrzeń biblioteczna została podzielona na dwie strefy studyjne. Strefy te sa wyraźnie oznaczone, a bibliotekarze i pracownicy ochrony regularnie sprawdzają, czy przestrzegane sa zasady w nich obowiazujące. W strefie zaznaczonej na zielono (quiet study) można rozmawiać szeptem, można pracować w grupie, telefon komórkowy trzeba wyciszyć, dzieci moga towarzyszyć rodzicom pod warunkiem, że nie będą przeszkadzały pozostałym czytelnikom. Natomiast w strefie czerwonej (silent study) pracuje się indywidualnie, obowiąuje zakaz rozmowy, a telefony komórkowe należy wyłączyć.

Biblioteka Docklands jest łatwo dostępna. Jest to przestrzeń bezpieczna, a dobrze oznakowane pomieszczenia sprzyjają efektywnemu wykorzystaniu biblioteki. Wyposażenie biblioteki zapewnia przestrzeń do nauki indywidualnej, miejsce do nauki w grupie oraz możliwość rozwijania umiejętności w zakresie wyszukiwania informacji.

\section{Kompetencje informacyjne}

Nowe technologie na stałe zagościły w życiu współczesnego człowieka. Telefon komórkowy czy Internet to dzisiaj jedne z głównych narzędzi pomocnych w wymianie doświadczeń, uczeniu się czy nawiązywaniu znajomości. Postępująca digitalizacja wymusza umiejętność obsługi „nowych mediów”, ale jej następstw nie można sprowadzić jedynie do sprawności technologicznych.

${ }^{5}$ M. Staporek: Ucz się bibliotekarzu ucz...: stypendia zagraniczne dla bibliotekarzy. EBIB Elektroniczny Biuletyn Informacyjny Bibliotekarzy. 2008, nr 8 (99). [online]. [dostęp: 28.09.2012]. Dostępny w World Wide Web: <http://www.ebib.info/2010/99/a.php?staporek>.

${ }^{6}$ Athens - konto uprawnia do uzyskania dostępu do różnych internetowych baz danych, czasopism elektronicznych i e-książek. 
Cyfryzacja kształtuje nowe sposoby myślenia, czucia i działania w społeczeństwie $^{7}$, ale niesie ze sobą także negatywne aspekty, takie jak cyfrowe wykluczenie, dzieląc społeczeństwo na tych, co umieją posługiwać się technologiami informacyjnymi i tych, którzy takich umiejętności nie posiadają. Potencjalnymi przyczynami wykluczenia cyfrowego sa przede wszystkim bariery społeczne, warunki ekonomiczne, brak możliwości technicznych, wiek, status społeczny, niepełnosprawność, bariery mentalne, niedostatki w wykształceniu ${ }^{8}$. Niektórym z tych czynników może skutecznie przeciwdziałać biblioteka. Popularność cyfrowych mediów i komunikacji online wywołuje nowe potrzeby użytkowników bibliotek, ale też stawia wyzwania dla edukacji bibliotecznej. Współczesna biblioteka dostosowuje się do potrzeb i zainteresowań „cyfrowego użytkownika”, motywuje do samodzielnego pogłębiania kompetencji informacyjnych i zapewnia odpowiednie zasoby edukacyjne. Stworzenie dostępu do usług informacyjnych, dostępu do informacji, a także wykorzystanie nowych technologii w procesie edukacji to wyzwania, które narzuca współczesnej bibliotece społeczeństwo informacyjne. „Biblioteki współtworzą warunki sprzyjające realizacji praw człowieka takich jak prawo do informacji, wykształcenia oraz dostępu do dziedzictwa narodowego" ". Umiejętności informacyjne i komunikacyjne zostały uznane za jedne z najważniejszych w XXI w. W dokumencie Organizacji Współpracy Gospodarczej i Rozwoju (Organisation for Economic Cooperation and Development), który dotyczy edukacji w erze cyfrowej, jest mowa o umiejętnościach wyszukiwania i interpretacji informacji10. Aby włączyć się w tworzenie społeczeństwa informacyjnego, biblioteka akademicka powinna posiadać odpowiednia infrastrukturę techniczna, która będzie służyła gromadzeniu, przetwarzaniu i przesyłaniu informacji na odległość.

W Wielkiej Brytanii funkcjonuje organizacja bibliotekarzy SCONUL (Society of College, National and University Libraries), której zadaniem jest dostarczanie bibliotekarzom korzystnych rozwiazań oraz promocja dobrych praktyk w środowisku bibliotek akademickich. SCONUL, określa cele kształcenia studentów w zakresie edukacji informacyjnej. Według aktualnej wersji modelu Siedem filarów information literacy, ${ }^{11}$ opublikowanej w kwietniu 2011 r., student po ukończeniu kursu z edukacji informacyjnej, powinien posiadać następujące umiejętności informacyjne:

${ }^{7}$ M. Filiciak, M. Danielewicz, M. Halawa, P. Mazurek, A. Nowotny: Młodzi i Media. Nowe media a uczestnictwo w kulturze. Raport Centrum Badań nad Kulturą Popularną Szkoły Wyższej Psychologii Społecznej. Warszawa, 2010, s. 6.

${ }_{8}$ P. Szefliński: Społeczeństwo informacyjne - o czym biblioteka XXI w. powinna wiedzieć? W: Biblioteki XXI w. Czy przetrwamy? II Konferencja Biblioteki Politechniki Łódzkiej. Łódź 2006, s. 31-42.

${ }_{9} \mathrm{~S}$. Kurek-Kokocinska: Społeczeństwo biblioteczne jako społeczeństwo informacyjne. „Zagadnienia Informacji Naukowej” 2001, nr 2, s. 45.

${ }_{10}$ OECD Learning to bridge the digital divide. Za: L. Derfert-Wolf: Information literacy - koncepcje i nauczanie umiejętności informacyjnych. EBIB Elektroniczny Biuletyn Informacyjny Bibliotekarzy. 2005, nr 1 (62). [online]. [dostęp: 8.12. 2008]. Dostępny w World Wide Web: <http://ebib.oss.wroc.pl/2005/62/derfert.php>.

11 Information literacy - zestaw umiejętności związanych ze zdobywaniem informacji, począwszy od rozpoznania potrzeb informacyjnych aż do jej właściwego wykorzystania. (L. Derfert-Wolf: Information Literacy - kształcenie umiejętności informacyjnych w bibliotekach akademickich. W: Przestrzeń informacyjna biblioteki akademickiej: tradycja i nowoczesność. Pod red. B. Antczak-Sabala, M. Kowalska, L. Tkaczyk. Toruń 2009, s. 185). 
- rozpoznawanie potrzeb informacyjnych,

- rozpoznawanie sposobów zaspokojenia potrzeb informacyjnych,

- tworzenie strategii wyszukiwania informacji,

- lokalizowanie i dostęp do informacji,

- porównywanie i ocena informacji uzyskanej z różnych źródeł,

- organizowanie, zastosowanie i prezentowanie informacji w sposób odpowiedni do sytuacji,

- synteza i tworzenie nowych zasobów wiedzy na podstawie istniejącej informacji ${ }^{12}$.

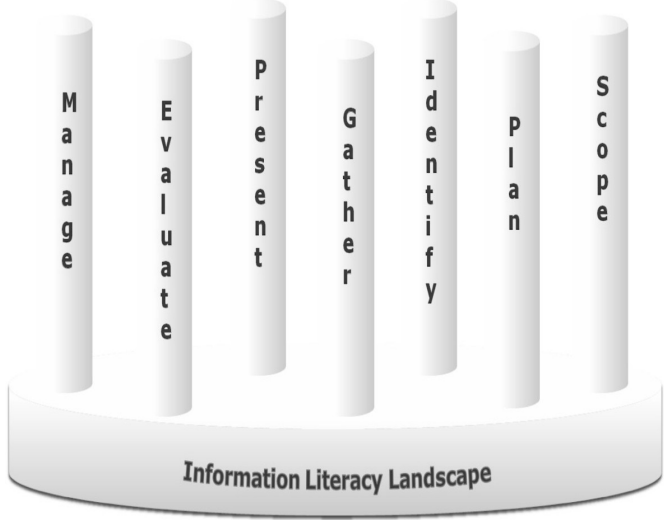

Rys. 1. SCONUL - siedem filarów information literacy

Źródło: Sconul. [online]. [dostęp: 2.10.2012]. Dostępny w Word Wide Web: <http://www.sconul. ac.uk/groups/information_literacy/publications/coremodel.pdf>.

Tradycyjny model biblioteki jako odrębnej jednostki stanowiącej składnicę informacji potrzebnych do uczenia się i nauczania nie jest już adekwatny do wymagań społeczeństwa informacyjnego i przemian zachodzących w sposobach zdobywania informacji. Okresem przełomowym w świadczeniu usług informacyjnych przez biblioteki było minione dziesięć lat, gdy zmieniły się narzędzia, metody, zmienili się użytkownicy i ich wymagania. Zmianie uległa forma komunikowania się na płaszczyźnie bibliotekarz - czytelnik. Użytkownik indywidualny stał się bardziej anonimowy, gdyż bezpośredni kontakt z użytkownikiem coraz częściej ustępuje miejsca pośrednim sposobom komunikacji. Współczesny użytkownik przeważnie oczekuje jedynie wskazówki, by dalej samodzielnie kontynuować poszukiwania. Taka informacyjna wskazówka jest strona internetowa, informatory o bibliotece, ulotki reklamujące poszczególne rodzaje usług ${ }^{13}$. Pewna część poszukiwanej informacji może

12 Information Skills in Higher Education: A SCONUL Position Paper. W: SCONUL [online]. [dostęp: 12.05.2008]. Dostępny w World Wide Web: <http://www.sconul.ac.uk/ groups/information_literacy/papers/Seven_pillars.html>. Za: L. Derfert-Wolf: Information Literacy - kształceñie umiejętności informacyjnych w bibliotekach akademickich. W: Przestrzeń informacyjna biblioteki akademickiej: tradycja i nowoczesność. Pod red. B. AntczakSabala, M. Kowalska, L. Tkaczyk. Toruń 2009, s.191.

${ }^{13}$ I. Sójkowska, F. Podgórski: Dokąd zmierza informacja? - czyli co oferuje biblioteka, a czego oczekuje użytkownik. Stan obecny i rozwój informacji naukowej w bibliotekach uczelni technicznych. W: Biblioteki XXI w. Czy przetrwamy? II Konferencja Biblioteki Politechniki Łódzkiej. Materiały Konferencyjne. Łódź 2006, s.417. 
być w bibliotece osiagalna, ale żadna biblioteka nie jest w stanie zgromadzić wszystkich możliwych materiałów, zmienia się więc działalność informacyjna biblioteki ${ }^{14}$. Biblioteka akademicka powinna dostarczać informacji w różnorodnych formach, zapewnić użytkownikowi niezbędne wsparcie w poszukiwaniu informacji. Biblioteka akademicka pełni wiele ról. Obejmują one: pomoc w realizacji programu studiów poprzez zapewnienie informacji i zasobów wspomagających proces zdobywania wiedzy; zapewnienie warunków i właściwej atmosfery umożliwiającej studentom naukę w odpowiadającym im tempie i dogodnym dla nich czasie, zapewnienie i upowszechnianie programów podnoszenia umiejętności w zakresie poszukiwania i korzystania z informacji ${ }^{15}$.

Koncepcja standardów nauczania kompetencji informacyjnych w Wielkiej Brytanii opiera się na dwóch zasadniczych celach - ma ułatwić studiowanie oraz ustawiczne kształcenie $\mathrm{w}$ trakcie pracy zawodowej. W procesach nauczania kładzie się nacisk nie na posługiwanie się technologiami informacyjnymi, ale na kształcenie samodzielności w korzystaniu z informacji ${ }^{16}$.

\section{Kompetencje informacyjne w Docklands Library}

Jedną z bibliotek, która należy do SCONUL i wdraża jego model siedmiu filarów jest Docklands Library University East of London. Biblioteka ta oferuje użytkownikom zarówno fizyczną, jak i wirtualną przestrzeń pozwalającą na:

- korzystanie ze zbiorów i usług biblioteki (przestronne wnętrze, tysiące książek, setki stacjonarnych komputerów, szerokopasmowe łącze internetowe, samoobsługowe kioski),

- aktywne uczestnictwo w kulturze (obszerna aula ze sceną umożliwiająca wystawianie przedstawień, organizację koncertów, spotkań, plakaty promujące, np. picie wody, recycling),

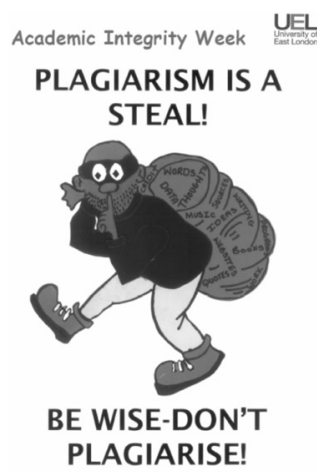

Rys. 2. Plakat przeciwko kopiowaniu cudzej pracy/pomysłu

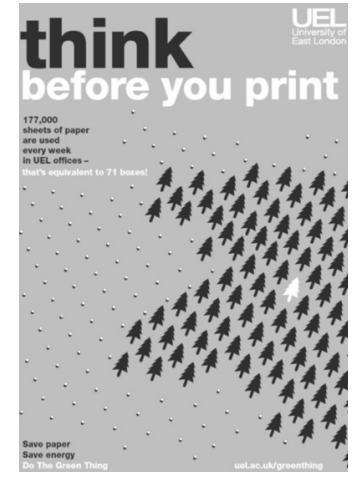

Rys. 3. Plakat promujący recycling

Źródło: UEL University of East London. [online]. [dostęp: 2.10.2012]. Dostępny w World Wide Web: <http://www.uel.ac.uk/apse/academic/documents/Plagiarism_is_a_steal[1]_LJones.pdf>.

${ }^{14}$ Zarządzanie biblioteką. Najnowsze kierunki w bibliotekarstwie brytyjskim: wybór tekstów. Pod red. I. Kemp, T. Wildhardt. Warszawa 1998, s. 16.

15 Ibidem, s. 44.

${ }^{16}$ W. Tychek: Umiejętności informacyjne użytkowników zasobów informacyjnych. „Bibliotekarz Warmińsko-Mazurski”. 2008, nr 3-4, s. 2. 
- uczenie się o mediach (kursy ECDL),

- liczne warsztaty przy pomocy ekspertów (z zakresu, np. zarządzania finansami, kreowania ścieżki kariery).

Ponieważ Internet stał się współcześnie środowiskiem edukacyjnym, miejscem odbioru informacji i uczenia się, a współcześni studenci preferują taki model zdobywania wiadomości, biblioteka UEL przygotowała interaktywny serwis online - Info Skills, którego podstawowym celem jest rozwijanie umiejętności informacyjnych studentów. Pośredni cel tego narzędzia to uzmysłowienie użytkownikom, że czas spędzony na pogłębianiu kompetencji informacyjnych to inwestycja na przyszłość. Info Skills ma być pomocne w przygotowywaniu młodych ludzi do życia w społeczeństwie informacyjnym, dlatego kładzie nacisk na opanowanie metod wyszukiwania, gromadzenia, selekcji i analizy informa$\mathrm{cji}^{17}$. Informacje umieszczane na stronie Info Skills Docklands Library wpisuja się w model siedmiu filarów SCONUL.

Informacje w Info skills podzielono na cztery duże zestawy: Identyfikowanie, Wyszukiwanie, Ewaluacja i Zastosowanie.

\section{Info skills}

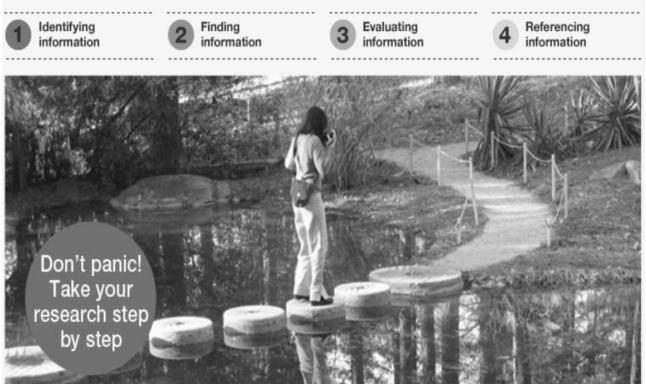

Rys. 4. Interfejs interaktywnego narzędzia Info skills

Źródło: UEL University of East London. [online]. [dostęp: 2.10.2012]. Dostępny w World Wide Web: $<$ http://infoskills.uelconnect.org.uk/>.

Część pierwsza, Identifying Information (rozpoznawanie, identyfikowanie potrzeb informacyjnych), składa się z czterech modułów. Pierwszy wyjaśnia i umożliwia użytkownikom zrozumienie ich potrzeb - dlaczego i jaka informacja jest im potrzebna. Pomoca są dwa filmy video: pierwszy, zawierający krótkie rady studentów UEL skierowane do nowo przybyłych na temat sposobów radzenia sobie z problemami informacyjnymi za pośrednictwem biblioteki, oraz drugi film, zawierający kilka uwag kierownika sekcji związanej z Informacja Naukową na temat pozyskiwania informacji dobrej jakości.

Drugi moduł koncentruje się wokół umiejętności sformułowania, zrozumienia konkretnego zagadnienia, tematu pracy, które użytkownik musi rozpracować. Przewodnik (w formacie PDF) wyjaśnia szczegółowo znaczenie poszczególnych słów, od których zaczynaja się tematy prac zaliczeniowych (np. porównanie, analiza, krytyka itp.). Kolejnym krokiem w pisaniu pracy jest identyfikacja zaso-

${ }^{17}$ C. Walsh, E. Mitchell, K. Travers: Info skills' at the University of East London. „Library and Learning Services (scholarly publications)". [online]. [dostęp: 12.2011]. Dostępny w World Wide Web: <http://hdl.handle.net/10552/1417>. 
bów bibliotecznych, określenie, jakie zasoby są dostępne, gdzie i w jaki sposób do nich dotrzeć, jaki jest charakter poszczególnych typów zasobów i w jakich sytuacjach z nich korzystać.

W module trzecim zamieszczona jest krótka charakterystyka typów źródeł dostępnych w bibliotece UEL: książki, czasopisma naukowe, Internet, prasa, materiały konferencyjne, archiwa i inne typy źródeł, np. raporty biznesowe, statystyczne. Przewodnik w formacie PDF dodatkowo prezentuje tabelkę, która przedstawia różnicę między pierwszym i drugim pochodzeniem źródła.

\begin{tabular}{|c|c|c|}
\hline $\begin{array}{l}\text { Resource } \\
\text { Zasoby }\end{array}$ & $\begin{array}{l}\text { Primary Source } \\
\text { Podstawowe źródło }\end{array}$ & $\begin{array}{l}\text { Secondary Source } \\
\text { Dodatkowe źródło }\end{array}$ \\
\hline $\begin{array}{l}\text { Books } \\
\text { Ksiqziki }\end{array}$ & $\begin{array}{l}\text { An autobiography } \\
\text { Autobiografia }\end{array}$ & $\begin{array}{l}\text { A biography. } \\
\text { Biografia }\end{array}$ \\
\hline $\begin{array}{l}\text { Journals } \\
\text { Czasopisma }\end{array}$ & $\begin{array}{l}\text { An article written by a scientist about } \\
\text { his own research. } \\
\text { Artykut napisany przez naukowca prezentujqcy } \\
\text { jego własne badaniat }\end{array}$ & $\begin{array}{l}\text { An article by an academic regarding } \\
\text { the involvement of the UN in Kosova. } \\
\text { Artykut naukowy, który dotyczy zaangażowania } \\
\text { ONZ w sytuację w Kosowie. }\end{array}$ \\
\hline $\begin{array}{l}\text { The Internet } \\
\text { Internet }\end{array}$ & $\begin{array}{l}\text { London Fashion Week's official } \\
\text { website. } \\
\text { Oficjalna strona internetowa Londyńskiego } \\
\text { Tygodnia Mody. }\end{array}$ & $\begin{array}{l}\text { A blog about London Fashion week. } \\
\text { Blogo Londyniskim Tygodniu Mody. }\end{array}$ \\
\hline $\begin{array}{l}\text { Newspapers and other } \\
\text { press } \\
\text { Gazetyi inne zasoby drukowane }\end{array}$ & $\begin{array}{l}\text { A news report on a current event. } \\
\text { Raport o bieżqcych, aktualnych wydarzeniach. }\end{array}$ & $\begin{array}{l}\text { An article by a political commentator } \\
\text { stating his views on a current event. } \\
\text { Artykut politycznego komentatora wyrażajqcego } \\
\text { swoje poglqdy. }\end{array}$ \\
\hline $\begin{array}{l}\text { Conference Proceedings } \\
\text { Materiaty konferencyjne }\end{array}$ & $\begin{array}{l}\text { A paper delivered on someone's own } \\
\text { research. } \\
\text { Artykut napisany na podstawie własnych } \\
\text { badań. }\end{array}$ & $\begin{array}{l}\text { A paper delivered by a researcher on } \\
\text { someone else's research. } \\
\text { Artykut napisany na podstawie badań innych } \\
\text { naukowców. }\end{array}$ \\
\hline $\begin{array}{l}\text { Specialist Resources } \\
\text { Zasoby specjalistyczne }\end{array}$ & $\begin{array}{l}\text { East London Theatre Archive which } \\
\text { displays material such as posters and } \\
\text { photographs. } \\
\text { Archiwum Teatru Wschodniego Londynu, które } \\
\text { posiada w swoim zbiorze, np. plakaty } i \\
\text { fotografie. }\end{array}$ & $\begin{array}{l}\text { WGSN, a fashion database, which } \\
\text { comments on current and future } \\
\text { trends in fashion. } \\
\text { Baza mody, która komentuje biezace oraz } \\
\text { przyszte trendy w modzie. }\end{array}$ \\
\hline
\end{tabular}

Rys. 5. Pochodzenia źródeł (tłumaczenie autorki)

Źródło: UEL University of East London. [online]. [dostęp: 2.10.2012]. Dostępny w World Wide Web: http://infoskills.uelconnect.org.uk/pages/identifying_information/42/types_of_sources.html.

Drugi dokument (również w formacie PDF) podaje listę dostępnych w UEL baz danych z podziałem na poszczególne dziedziny, np. informacji na temat edukacji należy szukać w proponowanych bazach danych: Australian Education Index, British Education Index, ERIC, EBSCO Education Research Complete, ESBCO Academic Search Complete. Pomoca jest krótki film video, w którym bibliotekarz dziedzinowy zachęca do korzystania z artykułów z czasopism naukowych jako wiarygodnego i najbardziej aktualnego źródła informacji.

Drugi blok prezentuje strategie wyszukiwania. Umieszczony tam przewodnik, w punktach podaje sposoby pozyskiwania źródeł, wyjaśnia użycie operatorów Boole'a, podkreśla, że wszelkie poszukiwania należy rozpocząć od własnej biblioteki, traktując ją jako punkt wyjścia do dalszych poszukiwań. Kolejnym 
etapem są elektroniczne źródła: bazy danych, czasopisma i e-booki dostępne również poza obszarem biblioteki i kampusu. Dostęp do nich możliwy jest dzięki posiadaniu specjalnego hasła Athens. Kolejno omawiane sa wyszukiwarki Google i witryny tematyczne, dostęp do innych bibliotek zrzeszonych w ramach organizacji SCONUL oraz wypożyczalnia międzybiblioteczna.

Kolejna część Info skills dotyczy ewaluacji i oceny wartości zdobytych informacji (Evaluating Information).

Bardzo szczegółowo omawiane są kryteria oceny informacji. Przykładem jest ewaluacja dotycząca autorstwa:

Sprawdź dane dotyczące autora/organizacji, której pracę czytasz:

- Czy to osoba znana i szanowana w swojej dziedzinie?

- Czy ma tytuł naukowy, taki jak doktor, profesor?

- Czy ta osoba wcześniej już publikowała na dany temat?

- Czy inni autorzy ją cytują?

- Czy ma jakieś powody, próbując przekonać cię do swojego punktu widzenia?

- Czy nie sa to materiały wyprodukowane przez organizację, która stara się coś sprzedać?

Podobnie szczegółowo opisana jest ocena relewancji i aktualności wyszukanych informacji.

Kolejny moduł w tym bloku dotyczy ewaluacji witryn internetowych. Internet może być znakomitym źródłem wiarygodnej i wysokiej jakości informacji, ale jego przeszukiwanie jest coraz trudniejsze. Natura Internetu jest taka, że publikowanie staje się coraz prostsze i nikt nie kontroluje tego procesu, dlatego do internetowych źródeł należy podchodzić z wielką ostrożnością i uwagą. Wnikliwej ocenie powinna być poddana: relewantność, dokładność, aktualność, kompletność, dostępność i wiarygodność prezentowanych na witrynach danych. Dokument PDF i dwa filmy instruktażowe video z poradami bibliotekarzy dziedzinowych i wykładowców UEL mają za zadanie pomóc studentom umiejętnie oceniać jakość wiedzy pozyskanej z Internetu.

Kolejna część poświęcona jest portalom społecznościowym, tj. Facebook i Twitter. Bibliotekarze UEL podkreślaja, że aktywne udzielanie się na forach i portalach umożliwia, poprzez dyskusję, wytropienie nowych, interesujących informacji.

Ostatni blok zagadnień poświęcony jest znajomości zastosowania pozyskanych danych, umiejętności odpowiedzialnego i etycznego korzystania z nich, znajomości problemów prawa autorskiego, ochrony danych, sporzadzania bibliografii. Film video dołączony do prezentowanych informacji zawiera wypowiedź pracownika kadry odpowiedzialnej za akademicką integralność, który zachęca do prawdy, uczciwości i sprawiedliwości w sporządzaniu prac zaliczeniowych, dyplomowych etc. Poruszany jest także temat plagiatu, korzystania z pomysłów innych osób czy instytucji bez uwzględniania ich w bibliografii.

Bardzo szeroko omówione jest zagadnienie dotyczące sporządzania bibliografii. Pierwszy prezentowany sposób to styl Harwardzki.

Drugi dokument dotyczy innego sposobu zaopatrywania pracy w bibliografię, stosowanego na wydziale psychologii UEL. Dodatkowym atutem są interaktywne quizy umożliwiające na bieżąco sprawdzenie wiedzy i umiejętności w tym zakresie.

Ostatni podpunkt Info skills dotyczy zagadnień prawa autorskiego. Prezentowany dokument udziela dokładnych instrukcji, z jakich materiałów i ile 
można kopiować: $5 \%$ z urywku lub jeden rozdział z książki; mniej niż 10\%, nie więcej jak 20 stron z krótkich książek, raportów bez rozdziałów; jeden artykuł z czasopisma, nie więcej niż 10 stron powieści, opowiadania; artykuły z gazet, ale bez reklam i fotografii; etc.

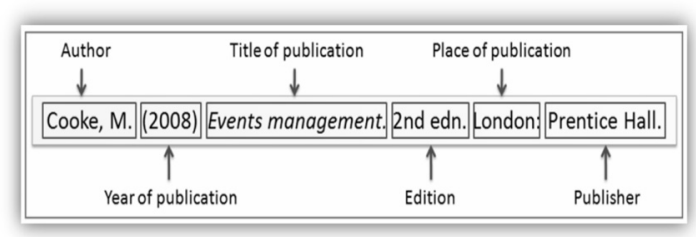

Rys. 6. Bibliografia, styl Harwardzki

Źródło: UEL University of East London. [online]. [dostęp: 2.10.2012]. Dostępny w World Wide Web: <http://infoskills.uelconnect.org.uk/pages/referencing_information/54/harvard_referencing.html>.

\begin{tabular}{|l|l|}
\hline Type of resource & \multicolumn{1}{|c|}{ Copy allowances } \\
\hline Books & $5 \%$ of extracts or one complete chapter of a book, whichever is larger. \\
\hline $\begin{array}{l}\text { Short books, reports or } \\
\text { pamphlets without chapters }\end{array}$ & Up to 10\% but no more than 20 pages in total. \\
\hline $\begin{array}{l}\text { Journals, Periodicals, } \\
\text { Conference proceedings }\end{array}$ & One article per journal. \\
\hline Poems and Short Stories & $\begin{array}{l}\text { No more than 10 pages of any poem or short story in an anthology covered } \\
\text { by the CLA licence. }\end{array}$ \\
\hline Newspaper articles & $\begin{array}{l}\text { Articles from newspapers covered by UEl's NLAAlicence, but not } \\
\text { photographs or advertisements. }\end{array}$ \\
\hline Law Reports & One case per set of law reports. \\
\hline
\end{tabular}

Rys. 7. Instrukcja, z jakich materiałów i ile można kopiować

Źródło: UEL University of East London. [online]. [dostęp: 2.10.2012]. Dostępny w World Wide Web: <http://infoskills.uelconnect.org.uk/pages/referencing_information/57/observing_copyright.html>.

Każdy z bloków tematycznych wieńczy zapewnienie o pomocy bibliotekarzy dyżurujących przy biurku zapytań. Podstrona Info skills zawiera również interesujące demonstracje (wykonane w programie Adobe Flash) dotyczące następujących problemów:

- wyszukiwanie książek tradycyjnych,

- wyszukiwanie e-booków,

- logowanie do konta bibliotecznego,

- dostęp do czasopism,

- dostęp do artykułów z czasopism,

- wiedza na temat wyszukiwania Informacji w elektronicznych bazach danych,

- dostęp do elektronicznych baz danych w kampusie i poza nim,

- postępowanie w przypadku zagubienia hasła dostępu do elektronicznych zasobów.

Informacje prezentowane w Info skills to zestaw umożliwiający studentom rozwinięcie kompetencji informacyjnych w bardzo przyjaznej i lubianej przez 
młode pokolenie formie (filmy video, quizy interaktywne). Info skills umożliwia uczenie się na odległość i przybliża zagadnienia informacji naukowej oraz zasady i techniki korzystania z zasobów biblioteki w sposób zdalny. Pracownicy biblioteki UEL otrzymują bardzo pozytywne komentarze od użytkowników na temat przydatności informacji znajdujących się w Info skills ${ }^{18}$. Poniżej zamieszczono wykres (Jak oceniasz tę stronę?), który przedstawia oceny zawartości Info skills wystawione przez studentów. 92\% respondentów powiedziało, że informacje $z$ tej strony są celnie dobrane, przydatne i użyteczne.

\section{How would you rate this site?}

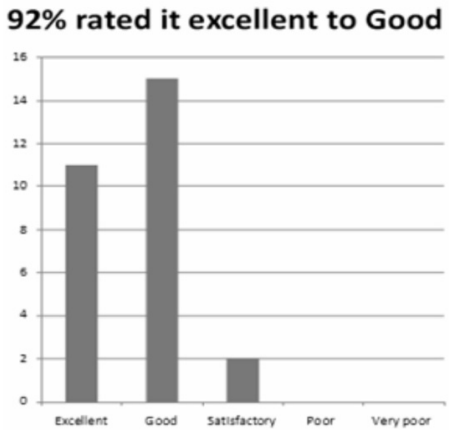

Rys. 8. Wykres przedstawiający ocenę Info skills przez studentów (Jak oceniasz tę stronę?)

Źródło: Slideshare. [online]. [dostęp: 2-10.2012]. Dostępny w World Wide Web: <http://www.slideshare.net/UEL_library/infoskillsevaluation>.

Użytkownicy Info skills wypowiedzieli się również na temat: „Co lubisz najbardziej w stronie Info skills? Wymienili kolejno: filmy video, quizy, łatwość w korzystaniu z niej, instrukcję cytowania, układ treści.

\section{What do you like most about the site?}

- Videos

- Quizzes

- Ease of use

- How to cite - more understandable and less confusing

- Layout

- Step by step

- Well organised site

- Time saving

- Everything in one place

Rys. 9. Odpowiedzi studentów na pytanie: Co lubisz najbardziej w stronie Info skills?

Źródło: Slideshare. [online]. [dostęp: 2.10.2012]. Dostępny w World Wide Web: <http://www.slideshare.net/UEL_library/infoskillsevaluation>.

${ }^{18}$ C. Walsh: Help! I've got an assignment to do... Info skills at the University of East London. „Library and Learning Services (scholarly publications)”. [online]. [dostęp: 28.09. 2012]. Dostępny w World Wide Web: <http://hdl.handle.net/10552/1430>. 
Interaktywne narzędzie, jakim jest Info skills, daje również możliwość wysyłania zapytań do bibliotekarza i rozmowę z nim na czacie. Użytkownicy chętnie korzystają z tych udogodnień. Pracownicy Biblioteki PSW mieli okazję zapoznać się z pracą bibliotekarza UEL obsługującego tzw. question point.

Szkolenie użytkowników w dużym stopniu przyczynia się do osiagnięcia przez bibliotekę wyznaczonych celów, jest formą promocji próbującą stymulować ukryte zapotrzebowania na usługi. Nie należy przyjmować za pewnik, że ludzie posiadają potrzebne umiejętności i potrafią dokonywać mądrych wyborów - twórcy portalu Info skills założyli, że trafiają do nich użytkownicy, którym należy pomóc znaleźć dostęp do źródeł informacji, odpowiednio je ocenić i zgodnie z prawem wykorzystać.

Biblioteka, której zależy na wizerunku i która chce promować siebie w sposób efektywny, musi wrócić do samego początku i zapewnić wysoki standard kształcenia użytkownika, które nie powinno ograniczać się do szkolenia wstępnego. Biblioteka UEL zaproponowała bardzo atrakcyjną i bogatą treściowo formę nabywania i doskonalenia kompetencji informacyjnych. Info skills to przykład dobrych rozwiązań, które będziemy starali się przenieść do Biblioteki PSW im. Papieża Jana Pawła II w Białej Podlaskiej.

\section{Bibliografia}

1. Derfert-Wolf L.: Information Literacy - kształcenie umiejętności informacyjnych $w$ bibliotekach akademickich. W: Przestrzeń informacyjna biblioteki akademickiej: tradycja i nowoczesność. Red. B. Antczak-Sabala, M. Kowalska, L. Tkaczyk. Toruń 2009, s. 191. Za: Information Skills in Higher Education: A SCONUL Position Paper. W: SCONUL [online]. [dostęp: 12.05.2008]. Dostępny w World Wide Web: <http://www.sconul.ac.uk/ groups/information_literacy/papers/Seven_pillars.html>.

2. Filiciak M., Danielewicz M., Halawa M., Mazurek P., Nowotny A.: Młodzi i Media. Nowe media a uczestnictwo w kulturze. Raport Centrum Badań nad Kulturą Popularną Szkoły Wyższej Psychologii Społecznej. Warszawa, 2010.

3. Kurek-Kokocińska S.: Społeczeństwo biblioteczne jako społeczeństwo informacyjne. „Zagadnienia Informacji Naukowej” 2001, nr 2, s. 43-63.

4. OECD Learning to bridge the digital divide. Za: L. Derfert-Wolf: Information literacy koncepcje i nauczanie umiejętności informacyjnych. EBIB Elektroniczny Biuletyn Informacyjny Bibliotekarzy. 2005, nr 1 (62). [online]. [dostęp: 8.12. 2008]. Dostępny w World Wide Web: <http://ebib.oss.wroc.pl/2005/62/derfert.php>.

5. Sójkowska I., Podgórski F.: Dokąd zmierza informacja? - czyli co oferuje biblioteka, a czego oczekuje użytkownik. Stan obecny i rozwój informacji naukowej w bibliotekach uczelni technicznych. W: Biblioteki XXI w. Czy przetrwamy? II Konferencja Biblioteki Politechniki Łódzkiej. Materiały Konferencyjne. Łódź 2006, s. 407-420.

6. Staporek M.: Ucz się bibliotekarzu ucz....: stypendia zagraniczne dla bibliotekarzy. EBIB Elektroniczny Biuletyn Informacyjny Bibliotekarzy. 2008, nr 8 (99). [online]. [dostęp: 28.09.2012]. Dostępny w World Wide Web: <http://www.ebib.info/2010/99/a.php?staporek>.

7. Szefliński P.: Społeczeństwo informacyjne - o czym biblioteka XXI w. powinna wiedzieć? W: Biblioteki XXI w. Czy przetrwamy? II Konferencja Biblioteki Politechniki Łódzkiej. Łódź 2006, s. 31-42.

8. Tychek W.: Umiejętności informacyjne użytkowników zasobów informacyjnych. „Bibliotekarz Warmińsko-Mazurski”. 2008, nr 3-4. [online]. [dostęp: 28.09.2012]. Dostępny w World Wide Web <http://www.wbp.olsztyn.pl/bwm/3-4_08-ie/umiejetnosci.htm>.

9. Waleszko M.: Zawodowy rozwój 2.0 dla bibliotekarzy: tworzenie osobistej sieci kształcenia online. Za: N. A. Cooke: Professional development 2.0 for librarians: developing 
an online personal learning network (PLN) (Rozwój zawodowy 2.0 dla bibliotekarzy: rozwój osobistej sieci kształcenia online). „Library Hi Tech News”. 2012, vol. 29, no. 3, s. 1-10. [online]. [dostęp: 24.06.2012]. Dostępny World Wide Web (dla subskrybentów). W: emeraldinsight.com.

10. Walsh C.: 'Help! l've got an assignment to do...'Info skills at the University of East London. „Library and Learning Services (scholarly publications)”. [online]. [dostęp: 28.09. 2012]. Dostępny w World Wide Web: <http://hdl.handle.net/10552/1430>.

11. Walsh C., Mitchell E., Travers K.: 'Info skills' at the University of East London. „Library and Learning Services (scholarly publications)". [online]. [dostęp: 28.09. 2012]. Dostępny w World Wide Web: <http://hdl.handle.net/10552/1417>.

12. Zarządzanie biblioteka. Najnowsze kierunki w bibliotekarstwie brytyjskim: wybór tekstów. Pod red. I. Kemp, T. Wildhardt. Warszawa 1998.

\section{Summary}

The article describes the interactive Info-Skills online service, developed by the employees of the Docklands Library University East of London, and aimed in improvement of students' information literacy. The UEL Library has changed a traditional model of library training into a very attractive and educative form of developing information competencies. Authors of this service assumed, that its users need help in searching information sources, their evaluation and proper usage. The article describes this service's contents as an example of British good practice, worth promotion and implementation in Polish libraries. 